\title{
STUDY OF THE PROPERTIES OF DRILL CUTTINGS AT THEIR USE AS TECHNOGENIC RAW MATERIALS FOR THE PRODUCTION OF BUILDING CERAMICS
}

\author{
Nadegda Rykusova ${ }^{1}$, Oleksii Shestopalov ${ }^{2}$, Liudmyla Shchukina ${ }^{3}$, Oleksandr Briankin ${ }^{4}$, \\ Yaroslav Galushka ${ }^{5}$ \\ ${ }^{1}$ Department of Chemical Engineering and Industrial Ecology, National Technical University "Kharkiv Polytechnical Institute", Kharkiv, \\ Ukraine \\ ORCID: http://orcid.org/0000-0003-0963-1805 \\ ${ }^{2}$ Department of Chemical Technique and Industrial Ecology, National Technical University "Kharkiv Polytechnical Institute", Kharkiv, \\ Ukraine \\ shestopalov.it@khpi.edu.ua \\ ORCID: http://orcid.org/0000-0001-6268-8638 \\ ${ }^{3}$ Department of Technology of Ceramics, Refractories, Glass and Enamels, National Technical University "Kharkiv Polytechnical Insti- \\ tute", Kharkiv, Ukraine \\ ${ }^{4}$ Department of Chemical Technique and Industrial Ecology , National Technical University "Kharkiv Polytechnical Institute", Kharkiv, \\ Ukraine \\ ORCID: http://orcid.org/0000-0002-7897-4417 \\ ${ }^{5}$ Department of Technology of Ceramics, Refractories, Glass and Enamels, National Technical University "Kharkiv Polytechnical Insti- \\ tute", Kharkiv, Ukraine \\ ORCID: http://orcid.org/0000-0003-1696-6769
}

\section{ARTICLE INFO}

Article history:

Received date 24.12.2019

Accepted date 16.01.2020

Published date 30.01 .2020

Section:

Building materials industry

D O I

$10.21303 / 2313-8416.2020 .001158$

\section{KEYWORDS}

\section{drilling}

drill cuttings

ceramic products

environmental pollution

biotesting

raw materials

mineral and chemical composition

particle size distribution

sintering

\section{A B S TRACT}

The possibility of utilizing drill cuttings in the technology of building ceramics is investigated.

Using the microscopic and X-ray spectral methods of analysis, the chemical and mineral composition and radiological properties of two samples of drill cuttings - waste gas drilling in the Poltava region - are determined.

Using the bioindication method, it is established that the studied drill cuttings are phytotoxic and harm the environment, therefore, they need to be disposed of. According to the radioactivity, the cuttings are investigated, they belong to the materials of the 1st class, which allows using them without restrictions in the construction and production of building materials.

The main ceramic-technological characteristics of the cuttings are determined. It is established that one of the cuttings in its composition is pre-burning and burning properties similar to clay rocks, the second cutting is unsintered psammite- aleuropelite material with a high content of calcium and magnesium carbonates, quartz and feldspar. The fundamental possibility of using the studied drill cuttings as the main raw material and mineral additives in the compositions of the masses to obtain wall ceramics with the necessary consumer properties is established.

(C) The Author(s) 2020. This is an open access article under the CC BY license http://creativecommons.org/licenses/by/4.0).

\section{Introduction}

The activity of oil and gas companies inevitably leads to anthropogenic impact on the environment. During the construction of wells, drill cuttings are formed - solid drilling waste, which consists of cuttings and drilling fluid. The danger of solid waste is that it contains various amounts of oil hydrocarbons, toxic components of drilling fluids and heavy metals, and therefore they are classified as the fourth hazard class of waste [1]. The negative impact of drill cuttings on the environment depends on their toxicity, which is due to the amount of contaminants used to prepare the drilling fluid. It is the toxicity of drill cuttings that requires their disposal and disposal.

Most of the existing methods for the disposal of drilling waste comes down to their disposal in specially equipped barns or located directly on the territory of the drilling station. Such storage of drilling waste has a negative effect on all components of the natural environment and leads to an alarming increase in the volume of their accumulation, in the absence of the necessary scale of their utilization and processing, and causes the withdrawal of land resources for a long time [2]. 
A promising direction for the disposal of solid drilling wastes is their use in the technology of materials and construction projects. To date, their use is known in the manufacture of products based on binders, as concrete fillers, as a component of burolite mixtures for strengthening road slopes, and cutting fillings during road construction [3]. Used as a filler for building bricks, tiles and shingles [4, 5].

Drill cuttings are also used in the technology of ceramic building materials. But their use, in contrast to the above, is more limited, which is explained by certain features of the cutting, in particular, the dependence of their composition and properties on the geological section of a particular well. At the same time, the involvement of cutting in large-tonnage ceramic technologies would increase the scale of their utilization and effectively solve environmental problems in hydrocarbon production areas, which makes comprehensive environmental and technological studies of this type of industrial waste relevant.

\section{Literature review and problem statement}

Drill cuttings can be disposed of in various types of building materials. Pre-neutralized drill cuttings can be used in the production of materials such as brick, expanded clay, small-sized building products based on binders. In this case, it seems possible not only to significantly reduce the cost of rough building ceramics, but also to improve a number of physical and mechanical characteristics of the product.

The literature [4] describes the use of coal waste in the composition of the mixture for the production of ceramic building products, due to the content of combustible components with high calorific value, it meets the fundamental principles of resource-saving technologies

The publication [5] gives brief characteristics of existing refinery and petrochemical wastes that are of interest in the manufacture of ceramic products both in terms of their utilization and in terms of improving the quality characteristics of ceramic products.

Significant potential for the production of ceramic wall materials has cuttings made from galvanic plants $[6,7]$.

In [7], it is shown that a brick based on a clay-cutting composition (5\%) is characterized by improved physical and mechanical properties. Given the high contents of heavy metals in the cutting (Cr, Zn, Ni, etc.), the authors perform leaching tests on the obtained materials, which show that pollutants during firing turn into stable compounds in the composition of ceramics.

Successful examples of the use of waste from thermal power plants (fly ash, ash residue) in the production of ceramic bricks are given in [8-10].

In the works of Chinese researchers, tails of iron ore beneficiation are used to obtain ceramic materials $[11,12]$.

A large number of articles are devoted to the use of organic waste for the production of building ceramics. One can distinguish various agricultural wastes: rice husk, raw cotton, sugar cane, tea production, etc. [13-15].

The aim of the research [16] is identification of the applicability of drill cuttings as an additive in the production of ceramic bricks by the plastic formation method. As a result of laboratory studies, it is determined that drill cuttings, which are included in the composition of the charge improves the quality of the feedstock with improved physico-chemical and operational characteristics.

In the publication [17] it is found that the addition of utilized drill cuttings in an amount of $5-10 \%$ of the mass to Portland cement increases the compressive strength of the obtained fastener by an average of 15-35\%, which allows the use of cementitious material for plugging oil and gas casing strings at intervals on which there is no water availability and there are specific rocks that isolate higher and lower-lying water horizons.

Thus, the creation of ceramic products using industrial waste is a common practice around the world.

From the analysis it follows that additional information is needed regarding the characteristics of various drill cuttings for use in ceramics.

\section{The aim and objectives of research}

The aim of research is the physicochemical and technological studies of drill cuttings of different chemical and mineral composition for their use as technogenic raw materials in wall ceramic technology. 
The objectives of research are:

- determination of the material and chemical-mineral composition of the waste, its ceramic-technological properties, ecotoxicity and radioactivity;

- determination of the function of these wastes in the compositions of ceramic masses and the possibility of their use in obtaining wall ceramics.

\section{Materials and methods of experimental researches}

Clay raw material is used as the base material, according to the existing classification [18] it is characterized as medium plastic, medium-sensitive to drying dusty loam. According to the characteristics of sintering, loam belongs to the red-burning and mid-sintering raw materials of low-temperature sintering (sintering temperature of $1090^{\circ} \mathrm{C}$ ).

As technogenic raw materials, two samples of drill cuttings are used, taken from different drilling intervals of two gas-bearing sections of the Poltava region (Ukraine), which are located at a distance of $45 \mathrm{~km}$ from each other.

The radiological properties of drill cuttings are investigated on a gamma radiation energy spectrometer SEG-002 “AKP-P” No. 1/97.

Cutting biotest is carried out according to the method described in DSTU ISO 11269-1:2004, which consists in germinated barley seeds in several growth substrates, one of which is the studied cutting. Other substrates - control soil, which is known to be of good quality, and sand control (sand). The seeds sprouted for five days in well-moistened substrates, after which the length of the roots and shoots is measured. The data obtained as a result of such an experiment are used to determine the inhibitory effect of cutting and the degree of their toxicity to soils.

The chemical and mineral composition of drill cuttings is determined using an ARL 9900 X-ray spectrometer. In addition, the mineral composition is studied by the petrographic method using an MIN-8 optical microscope.

For drill cuttings by standard methods, their granulometric composition and the content of coarse-grained inclusions are determined [19], the plasticity of the cuttings is studied by the method of balancing cone on a P. Boychenko according to the instructions for his work.

Thermal analysis of drill cuttings is carried out using a STA 409 PC Luxx synchronous thermal analyzer.

To make ceramic masses, raw materials in an air-dry state are crushed to pass through a No. 2 sieve. Samples are formed by the plastic method at normal molding moisture of the masses, they were previously rolled for 24 hours. After drying, the samples are burned in a laboratory muffle furnace at a temperature of $950{ }^{\circ} \mathrm{C}$ for one hour.

\section{Study of the radioactive and ecotoxic properties of drill cuttings}

\section{1. Characterization of cuttings and their macroscopic description}

In this study, two samples of drill cuttings taken from various gas-bearing areas of the Poltava region are examined, which are located at a distance of about $45 \mathrm{~km}$.

The first sample (laboratory code No. 1) is taken at the Sorochynske gas condensate field from a different drilling interval $(220-2400 \mathrm{~m})$. According to the lithological section provided by the geological and technical order, this interval includes various rocks, among which clay rocks in the form of clay and mudstone predominate. In a smaller and approximately similar amount, the section includes sand and sandstone, as well as carbonate-bearing rocks (marl, chalk and limestone). The second sample (laboratory code No. 2) is taken from East Poltava Square in the Chutovo District of the Poltava Region (the depth of selection is unknown).

Representative samples of drill cuttings are masses in the form of pastes with humidity at the level of 45-50\%. Samples were dried to an air-dry state and coarsely ground by hand (Fig. 1).

It can be seen from the figure that the dried samples are somewhat different in appearance. Sample No. 1 has a heterogeneous color with a smear of the substance of brown, green and white colors. On the contrary, sample No. 2 is more uniform with a predominance of gray. Organoleptic, the first sample has a "greasy" consistency, the second is more "dry" and visually contains more solid inclusions that do not break when crushed.

A qualitative reaction to the presence of calcium carbonates $(10 \% \mathrm{HCl}$ solution) shows more than "boiling" of cutting No. 1, but still of medium intensity. Under the influence of the acid 
solution on the cutting No. 2, "boiling" of medium intensity is also observed, but it is hampered by the presence of a hydrophobic substance in the cutting, which prevented the solution from wetting the particles of the cutting. The reaction of cutting to the action of an acid solution indicates the presence of active calcium carbonates in them.

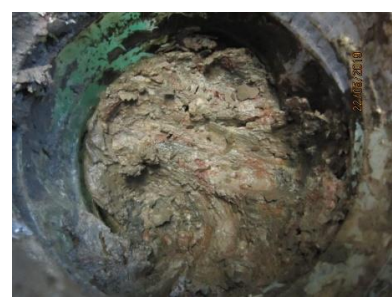

$a$

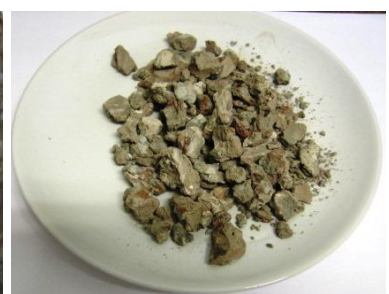

$b$

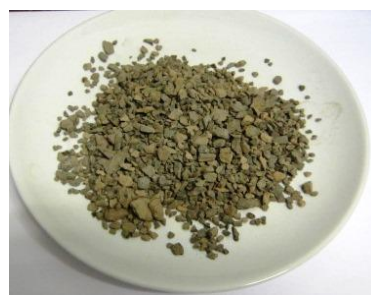

$c$

Fig. 1. General view of samples of drill cuttings: $a$-representative sample of drill cuttings No. 1; $b$-sample No. 1 in the air-dry state; $c$ - sample No. 2 in the air-dry state

\section{1. 1. Radioactive properties of cuttings}

According to the standards for ceramic raw materials, any new raw materials, especially of technogenic origin, must undergo radiological control.

In this work, the study of the radioactive properties of cuttings is carried out on sample No. 2, which contains more rigid components and, probably, more minerals. Measurements of the specific activity of radionuclides are carried out on a gamma-ray energy spectrometer, as a result of which the spectrum of radioactive isotopes $\mathrm{Ra}$, Th and $\mathrm{K}$ is taken (Fig. 2).

According to the test results, data are obtained on the specific activity of natural radionuclides: Ra-226 - 96.1 Bq/kg, Th-232 - 44.3 Bq/kg, K-40 - $1030 \mathrm{~Bq} / \mathrm{kg}$. The effective specific activity is:

$$
\mathrm{A}_{e f}=\mathrm{A}_{\mathrm{Ra}}+1.31 \mathrm{~A}_{\mathrm{Th}}+0.085 \mathrm{~A}_{\mathrm{K}}=242 \mathrm{~Bq} / \mathrm{kg} \text {, }
$$

which is below the acceptable level for the first class of raw materials with a specific activity of natural radionuclides up to $370 \mathrm{~Bq} / \mathrm{kg}$.

So, from the data presented, it can be concluded that the studied radioactivity sample belongs to the materials of the first class, which allows the use of this cutting without restrictions in the construction and production of building materials.

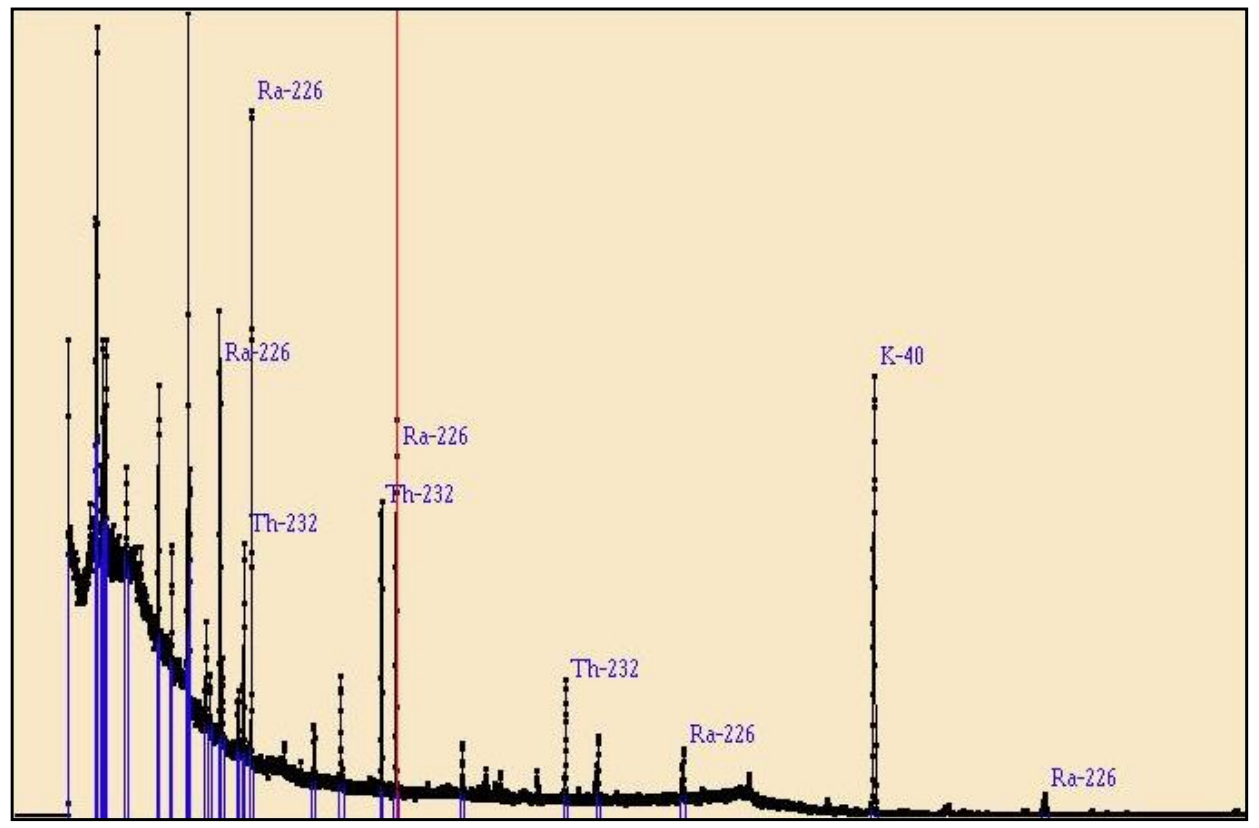

Fig. 2. The characteristic spectrum of radioactive elements of the cutting 


\section{1. 2. Ecotoxic characteristics of the cuttings}

The aim of this research stage is to assess the toxicity of drill cuttings using a growth test on plants, since plants are very sensitive to changes in environmental conditions, manifested in possible morphological changes (curvature of shoots, stems, root system, leaves, etc.) in case of contamination the soil.

Biological testing of cutting samples was carried out in accordance with DSTU ISO 112691:2004 [20]. As a test object, barley seeds are used. In the study of cuttings, three growth substrates are used: test soil (cutting), control soil of good quality (soil for flowers) and sand control. All substrates should have a moisture content of $\sim 70 \%$, and barley seeds are planted in them, germinated for two days in Petri dishes (Fig. 3). According to the standard, seeds are not grown well for five days, but already after a day there is noticeable plant growth in high-quality soil and sandy substrate, but not in cutting No. 2 (Fig. 4).

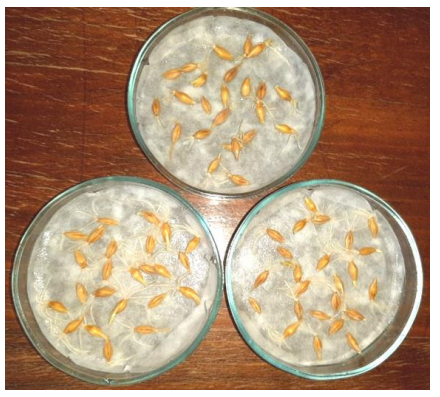

Fig. 3. Germinated seeds before planting

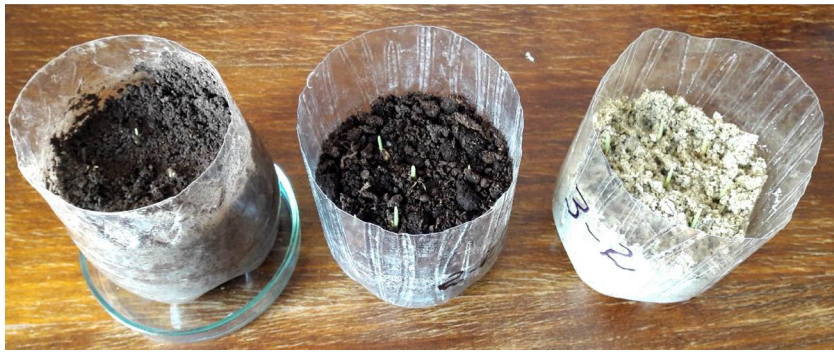

Fig. 4. Germination of plants in substrates in a day

After germination for five days under special conditions, plant samples are obtained, shown in Fig. 5, which are removed from the soil with subsequent washing of the roots in water (Fig. 6). From Fig. 5 it is possible to see that the seeds are of high quality, because they germinated both in the soil and in the sand (sand control).

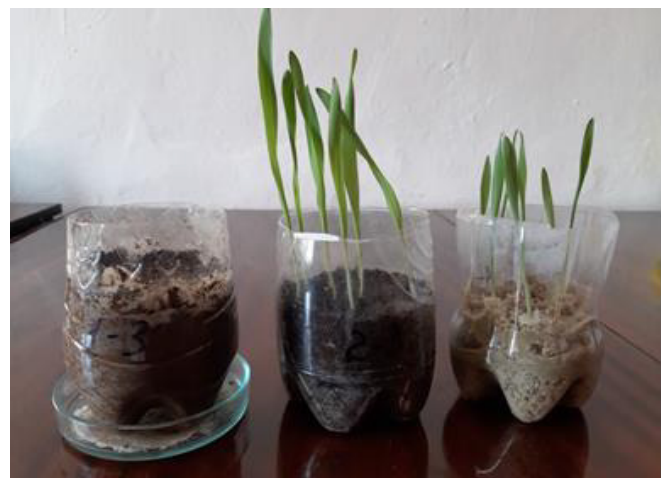

Fig. 5. Type of plants in various substrates after germination for five days

For plants as phytoindicators, the lengths of the roots and upper parts (shoots) are measured. The results of studies of changes in the morphological parameters of phytoindicators for each substrate with three parallel experiments are given in Table 1. The data in the Table 1 and Fig. 6 in- 
dicate that cutting No. 2 inhibits plant growth. Despite the growth of roots in the cutting, the upper part of the plants practically does not develop.

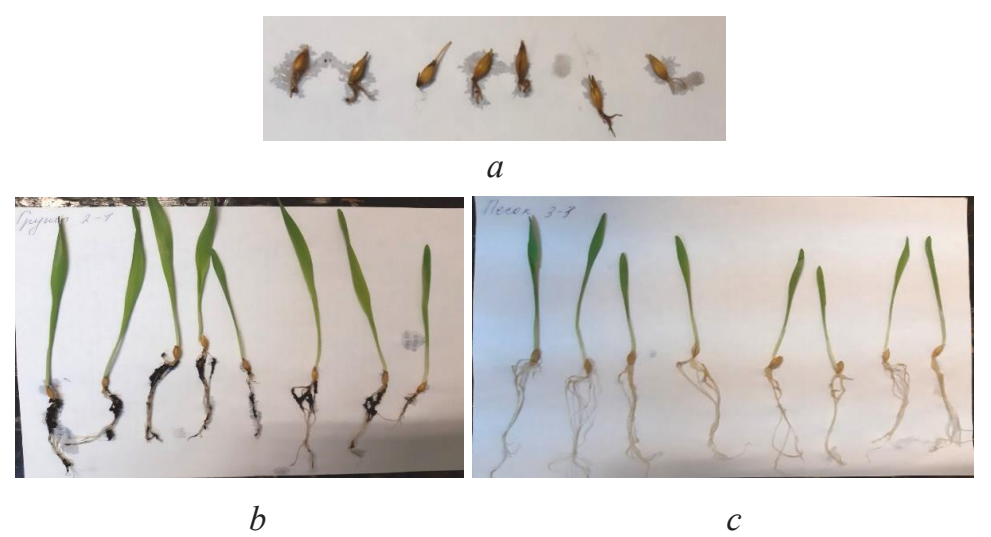

Fig. 6. Plants after extraction from substrates: $a$ - cutting No. $2 ; b$ - high-quality soil; $c$ - sand control

The magnitude of the effect of inhibition of plant growth (or phytoxic effect E) according to the author [21] is determined by the formula:

$$
E=(L c-L r) / L c \cdot 100 \%
$$

where $L c$-average length of plant roots in the control soil, $\mathrm{mm} ; L r$ - average length of plant roots in research soil, $\mathrm{mm}$.

Table 1

Morphological indicators of phytoindicators of research plants

\begin{tabular}{|c|c|c|c|c|c|c|c|c|}
\hline \multirow{2}{*}{$\begin{array}{c}\text { Substrate } \\
\text { sample number }\end{array}$} & \multicolumn{8}{|c|}{ The length of the root and top of the plant in $\mathrm{mm}^{*}$} \\
\hline & 1 & 2 & 3 & 4 & 5 & 6 & 7 & 8 \\
\hline \multicolumn{9}{|c|}{ Cutting No. 2} \\
\hline $1-1$ & $11 / 1$ & $8 / 0$ & $10 / 0$ & $12 / 0$ & $11 / 0$ & $9 / 0$ & - & - \\
\hline $1-2$ & $13 / 1$ & $3 / 0$ & $13 / 1$ & $3 / 0$ & $2 / 0$ & - & - & - \\
\hline $1-3$ & $8 / 1$ & $8 / 0$ & $8 / 2$ & $8 / 0$ & $11 / 2$ & $3 / 0$ & $6 / 1$ & - \\
\hline \multicolumn{9}{|c|}{ High-quality soil } \\
\hline $2-1$ & $74 / 129$ & $79 / 131$ & $94 / 136$ & $79 / 112$ & $54 / 86$ & $84 / 35$ & $80 / 129$ & $53 / 112$ \\
\hline $2-2$ & $62 / 93$ & $57 / 87$ & $62 / 95$ & $60 / 128$ & $82 / 100$ & $84 / 119$ & $87 / 108$ & $60 / 85$ \\
\hline $2-3$ & $81 / 135$ & $94 / 125$ & $111 / 151$ & $92 / 135$ & $80 / 123$ & $97 / 140$ & $86 / 129$ & $75 / 122$ \\
\hline \multicolumn{9}{|c|}{ Sand control } \\
\hline $3-1$ & $106 / 86$ & $138 / 106$ & $94 / 95$ & $113 / 94$ & $94 / 104$ & $110 / 105$ & $104 / 106$ & $104 / 98$ \\
\hline $3-2$ & $104 / 93$ & 107/91 & $109 / 87$ & $112 / 94$ & $109 / 92$ & $111 / 100$ & $103 / 93$ & $105 / 89$ \\
\hline $3-3$ & $114 / 98$ & $101 / 125$ & $99 / 74$ & $103 / 81$ & $96 / 90$ & $104 / 92$ & $90 / 87$ & $91 / 75$ \\
\hline
\end{tabular}

Note: *-the numerator shows the length of the root, the denominator shows the length of the top

According to [22], if the inhibition effect is $20 \%$ or more, then the substrate has a phytotoxic effect on plants.

To calculate the phytotoxic effect, the average lengths of plant roots from cutting and high-quality soil are compared. But first, the differences between the variances of different series of measurements on cutting and high-quality soil are estimated using the research F-criterion, comparing it with the tabulated value [23] for the number of experiments performed and the significance level $\alpha=0.05$. It is found that for a series of experiments conducted on cutting $(1-1,1-2,1-3)$ and high-quality soil (2-1, 2-2, 2-3), their dispersions within the series are estimates of the same general variance, and the differences between them are insignificant with a confidence probability 
of $P=99.95$. Therefore, to calculate the average root length, this parameter was taken for all plants in the framework of the series: for plants grown in cutting - 18 pcs., for plants grown in high-quality soil -24 pes.

Based on the data of Table 1, the average root length of plants grown in cutting is $6.1 \mathrm{~mm}$, and that of plants grown in quality soil is $77.8 \mathrm{~mm}$. Hence the effect of inhibition of plant root growth is $E=92.2 \%$. Similar calculations carried out along the length of the shoots show that $E=99.6 \%$.

To compare soil toxicity by the growth test of a phytoindicator, the author [24] proposes a scale of soil toxicity levels (Table 2).

Table 2

Soil toxicity scale

\begin{tabular}{cc}
\hline Phytotoxic effect (levels of suppression of growth processes), $\%$ & Toxicity level \\
\hline $0-20.0$ & Absence or weak suppression \\
$20.1-40.0$ & middle level \\
$40.1-60.0$ & Above middle average \\
$60.1-80.0$ & high level \\
$80.1-100.0$ & Maximum level
\end{tabular}

So, according to the suppression of growth processes $(92.2 \%$ for roots and $99.6 \%$ for shoots), cutting No. 2 is characterized by a maximum level of phytotoxicity, which indicates its negative effect on the soil and vegetation cover of the site occupied by it.

Similarly, biological testing of cutting No. 1 is carried out, the results of which are shown in Fig. 7 and in Table 3.

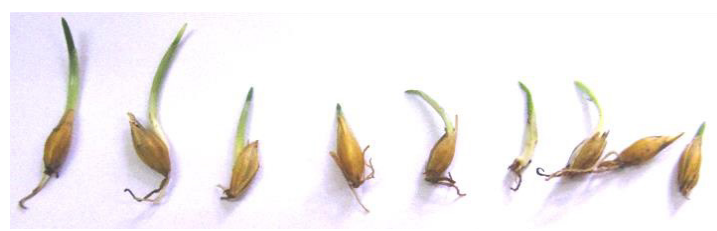

Fig. 7. Plants after extraction from cutting No. 1

Table 3

Morphological indicators of phytoindicators of research plants grown in cutting No. 1

\begin{tabular}{cccccccccc}
\hline \multirow{2}{*}{ Sample } & \multicolumn{7}{c}{ The length of the root and top of the plant in $\mathbf{m m *}$} \\
\cline { 2 - 10 } & $\mathbf{1}$ & $\mathbf{2}$ & $\mathbf{3}$ & $\mathbf{4}$ & $\mathbf{5}$ & $\mathbf{6}$ & $\mathbf{7}$ & $\mathbf{8}$ \\
\hline $1-1$ & $10 / 15$ & $11 / 21$ & $3 / 12$ & $18 / 6$ & $19 / 5$ & $10 / 13$ & $8 / 12$ & $5 / 10$ \\
$1-2$ & $11 / 14$ & $10 / 22$ & $4 / 11$ & $17 / 7$ & $18 / 6$ & $9 / 12$ & $9 / 12$ & $6 / 11$
\end{tabular}

Note: *-the numerator shows the length of the root, the denominator shows the length of the top

The phytotoxic effect of cutting No. 1 is slightly lower than cutting No. 2, but according to calculations carried out on the roots of plants, it is still high and amounts to $E=86.5 \%$, and on shoots $-E=84.8 \%$. The toxicity level of such cutting is also maximum.

Thus, ecotoxic evaluation of cutting No. 1 and No. 2 shows that both wastes have a negative phytotoxic effect on plants, and their soils are characterized by a maximum level of toxicity. This confirms the need to implement measures for the disposal of land plots occupied by cutting, including in the direction of disposal of these wastes in ceramic technologies.

\section{2. Study of the composition and technological properties of drill cuttings}

\section{2. 1. Study of the chemical and mineral composition of cuttings}

To determine the chemical composition of the cutting, they underwent heat treatment, since the organic substance present in them interfered with the determination of elements. The chemical 
composition of the calcined cutting, determined by X-ray spectrometry, are given in Table 4, the mineral composition - in Table 5.

Additionally, a petrographic analysis of cuttings in the initial state is carried out, the description of which is given below.

Cutting No. 1. The cutting is greasy to the touch, slides in water with a slight increase in volume and breaks up into small pieces and thin plates. The sample reacts to a $10 \%$ hydrochloric acid solution.

Under the microscope, the cutting consists of quartz grains and clay material (approximately equal amounts), carbonates and feldspars are present in a smaller amount. Quartz is present in the form of unpainted transparent debris grains of irregular shape up to 3.5-4 $\mathrm{mm}$ in size. Often on the surface of the grains, films and smears of thin flakes of mica and carbonates are noted.

Table 4

Chemical composition of drill cuttings per calcined substance

\begin{tabular}{ccc}
\hline Oxides & Drilling No. 1 & Drilling No. 2 \\
\hline $\mathrm{SiO}_{2}$ & 67.11 & 60.34 \\
$\mathrm{Al}_{2} \mathrm{O}_{3}$ & 15.40 & 16.39 \\
$\mathrm{TiO}_{2}$ & 0.57 & 0.75 \\
$\mathrm{Fe}_{2} \mathrm{O}_{3}$ & 4.90 & 5.89 \\
$\mathrm{~K}_{2} \mathrm{O}$ & 2.28 & 4.48 \\
$\mathrm{Na}_{2} \mathrm{O}$ & 1.50 & 1.14 \\
$\mathrm{CaO}$ & 6.17 & 7.79 \\
$\mathrm{MgO}$ & 1.83 & 3.00 \\
$\mathrm{P}_{2} \mathrm{O}_{5}$ & 0.10 & 0.15 \\
$\mathrm{Cr}_{2} \mathrm{O}_{3}$ & 0.02 & 0.02 \\
$\mathrm{MnO}$ & 0.13 & 0.06
\end{tabular}

Table 5

The mineral composition of the drillings

\begin{tabular}{ccc}
\hline Minerals & Drilling No. 1 & Drilling No. 2 \\
\hline Quartz & 36.3 & 34.8 \\
Kaolinite & 8.9 & 6.3 \\
Rutile & 0.7 & - \\
Anatase & - & 0.7 \\
Hydromica & 27.7 & 23.6 \\
Montmorillonite & 11.3 & 10.2 \\
Calcite & 7.6 & 9.6 \\
Dolomite & - & 2.8 \\
Anorthite & 2.5 & 4.3 \\
Microcline & 3.2 & 5.0 \\
Albite & 1.8 & 1.2 \\
Pyrites & 0.4 & 1.5
\end{tabular}

A clay substance stained with gel-like iron hydroxides in yellow-brown to red color is in a highly dispersed state, has medium birefringence and a light refractive index of $1.510 \leq N$ sum $\leq 1.570$. It should be noted that gelled iron hydroxides mask birefringence and increase the Nsum of clay substance. Clay substance is represented by aggregate-sprout of complex composition and, probably, has kaolinite-montmorillonite composition with impurities (7-10\%) of thin hydromica scales, evenly distributed in the clay mass.

Carbonates in the form of calcite are found mainly in streaks and spots of white color, quite rarely - in the form of inclusions uniformly interspersed in the clay mass. Calcite forms finely dis- 
persed aggregates with a grain size $<0.004 \mathrm{~mm}$ with single polysynthetic double and hand-shaped crystals up to $0.02-0.03 \mathrm{~mm}$ in size. The amount of carbonates is from $1-3 \%$ to $80-85 \%$.

Feldspars with a particle size of up to $1 \mathrm{~mm}$ are represented by partially sosuritized (weathered) potassium feldspar (microcline) and partially pelitized (modified) acidic plagioclase (closer to albite). The number of feldspar is $5-10 \%$.

Accessory minerals (up to $2 \%$ in total) are represented by zircon, rutile, leucoxene, iron hydroxides, etc.

Cutting No. 2. Presented by sand and wood material. Sand material with a grain size of 0.1-1 mm brownish, greasy to the touch, actively reacts to a $10 \%$ solution of hydrochloric acid. Grus - sharply fragmented pieces up to 5-7 $\mathrm{mm}$ in size, relatively strong and dense, do not become sap in water at all.

Under the microscope: psammite (sand)-aleuropelite material consists of finely divided and polysynthetic doubled carbonate (calcite + dolomite), quartz, feldspar and a minor (up to 10-15\%) clay admixture.

Black pieces are a finely divided clay substance, in places with felt-like extinction and a refractive index of Nsum $\sim 1.565$ with weakly medium birefringence. It is difficult to determine the mineral composition of a clay substance, since it is very changed. Among the total clay mass, up to $10-15 \%$ of thin lath (flakes) hydromica, individual grains of quartz, feldspar and calcite stand out.

Dark brown pieces (no less durable than black pieces) are represented by finely dispersed clay material, intensely colored in dark brown, gel-like iron hydroxides, usually translucent only along the edge of the grains (refractive index $N>1.560$ ). In the grains of finer disseminated carbonate (up to 3-5\%), very few (as in black pieces) quartz and feldspar, there are practically no hydromica. The determination of the clay mineral composition in the bulk of sample No. 2 is hampered by the presence of light carbonate.

Thus, according to petrography, it is possible to conclude that sample No. 1 in many respects can be attributed to clay of complex polymineral (kaolinite, montmorillonite, hydromica) composition. Sample No. 1, like sample No. 2, is not sustained in the quantitative distribution of mineral phases.

Sample No. 2 is represented by aleuropelite-psammite-grus material. Given that the grusof this sample does not become sap in water and is strong enough, its mudstone can be considered. It is likely that during the heat treatment of samples fires can occur at relatively low temperatures $\left(\sim 1000 \pm 100^{\circ} \mathrm{C}\right)$ and even swelling.

An analysis of the chemical and mineral composition of drill cuttings shows that both wastes are aluminosilicate materials with a high content of iron oxide. Also, in both cuttings, calcium oxide is present in significant quantities, and in the second cutting, magnesium and potassium oxides are also present. The clay substance of the cutting is polymineral and is represented by kaolinite, montmorillonite and hydromica. But, at the same time, the cutting is different in that cutting No. 1 contains much more clay material than cutting No. 2, for which it is rather an impurity. Cutting No. 2 also contains mudstone and a lot of calcium and magnesium carbonates in the form of psammite (sand)-aleuropelite material, which is the basis of this cutting.

Based on this, it can be assumed that cutting No. 1 can be positioned as raw material close to clay, and cutting No. 2, most likely, will not exhibit the properties of clay rocks in the study of its ceramic-technological properties.

\section{2. 2. Study of ceramic-technological properties of cuttings}

At this stage of the study, the following technological properties of cutting are considered:

- content of coarse inclusions;

- grading;

- ductility;

- air shrinkage and sensitivity to drying;

- caking ability.

According to the results of studying the content of coarse inclusions (Table 6), it can be concluded that both samples of cutting belong to the group of raw materials with a high content of coarse inclusions [25]. Moreover, the residue on sieve No. 05 for cutting No. 2 is four times greater 
than cutting No. 1 . The sieving of these residues showed that their granulometry is approximately similar for both helmets - about half of the residues are fine fraction (less than $1 \mathrm{~mm}$ ), and the second half represents a large fraction (more than $1 \mathrm{~mm}$ ).

Table 6

The results of determining the content of coarse inclusions in the cutting

\begin{tabular}{ccc}
\hline \multirow{2}{*}{ Particle size } & \multicolumn{2}{c}{ Particle content, \% } \\
\cline { 2 - 3 } & cutting No. 1 & cutting No. 2 \\
\hline more than $0.5 \mathrm{~mm}$ & 11.2 & 45.3 \\
\hline more than $5 \mathrm{~mm}$ & sifted residue on sieve No. 05 & 3.7 \\
$3-5 \mathrm{~mm}$ & 9.2 & 8.9 \\
$2-3 \mathrm{~mm}$ & 9.2 & 9.2 \\
$1-2 \mathrm{~mm}$ & 10.9 & 33.6
\end{tabular}

When studying the granulometric composition of cuttings by the Rutkovsky method, they are crushed and passed through a No. 1 sieve, which makes it possible to assess the possibility of using cuttings in a finely ground state in wall ceramic technology. The results of the study of cutting granulometry are shown in Fig. 8.

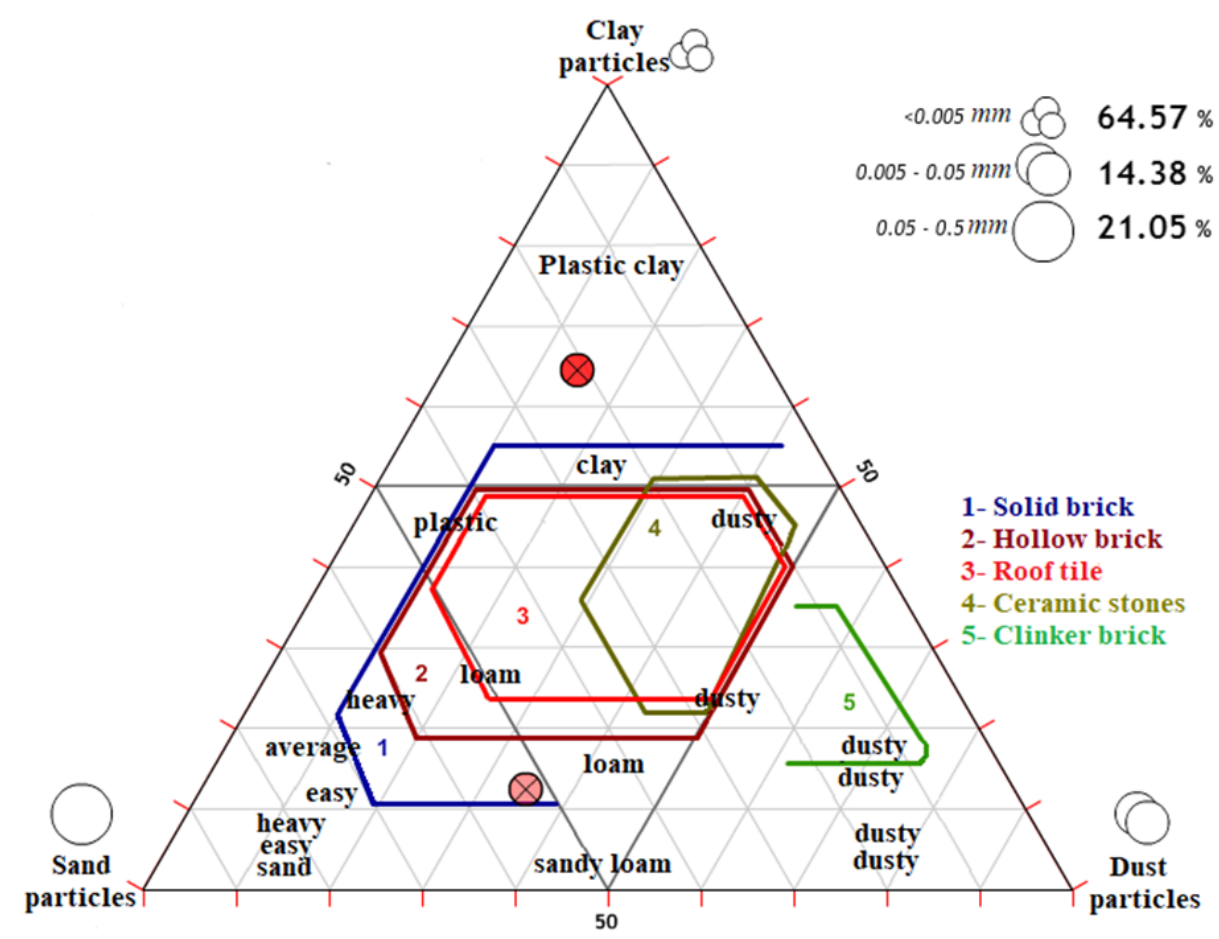

Fig. 8. The position of the points of the granulometric composition of the cutting in the Okhotin and Berkman-Melnykova combined diagram

According to the diagrams, cutting No. 1 refers to plastic clays, and cutting No. 2 - to dusty loams. In its pure form, cutting No. 1 can't be used in any of the coarse-grained industries, cutting No. 2 - can only be used in the production of solid brick. But the position of the points of particle size distribution in the diagrams only on this basis indicates a low quality of cutting as a ceramic raw material.

The plasticity of the wet dough made of cutting is determined by the method of the balancing cone, which provides for the determination of the absolute moisture content of the test in different states, followed by the determination of humidity in the state of rolling border graphically. The results of determining plasticity are given in Table 7. 
According to the plasticity classification for clay raw materials, cutting No. 1 refers to the near-world plastic raw material, and No. 2 cutting refers to slightly plastic.

Table 7

Dough humidity in extreme conditions

\begin{tabular}{cccc}
\hline Cutting & $\begin{array}{c}\text { Absolute humidity in the state } \\
\text { of the lower yield stress, \% }\end{array}$ & $\begin{array}{c}\text { Absolute humidity in the state } \\
\text { of the rolling border, \% }\end{array}$ & Plasticity number \\
\hline 1 & 48.90 & 34.50 & 14.40 \\
2 & 23.89 & 18.30 & 5.59
\end{tabular}

According to the drying properties (Table 8), cutting is characterized by low sensitivity to drying, but cutting No. 1 has a high air shrinkage, which is explained by the presence of montmorillonite in it with a greater dispersion.

Table 8

Cutting-based drying properties of the masses

\begin{tabular}{ccc}
\hline Cutting & Nosova sensitivity coefficient & Relative linear air shrinkage, \% \\
\hline 1 & 0.83 & 12.4 \\
2 & 0.32 & 0.51
\end{tabular}

Sintering ability of cuttings is determined by water absorption of products of their firing at temperatures of $950{ }^{\circ} \mathrm{C}$ and $1100^{\circ} \mathrm{C}$. The appearance of the obtained samples is shown in Fig. 9 .

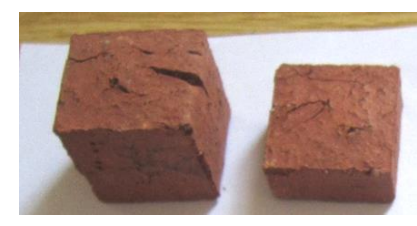

$a$

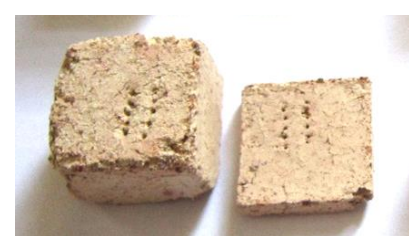

c

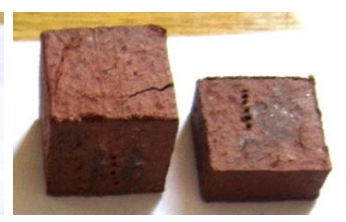

$b$

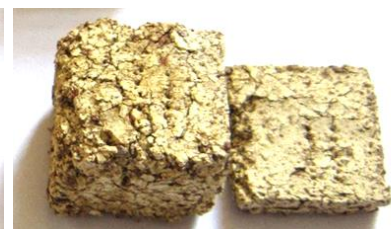

$d$

Fig. 9. Cutting sintering products: $a$ - cutting No. $1\left(950^{\circ} \mathrm{C}\right) ; b$ - cutting No. $1\left(1100^{\circ} \mathrm{C}\right)$; $c$ - cutting No. $2\left(950^{\circ} \mathrm{C}\right) ; d$ - cutting No. $2\left(1100{ }^{\circ} \mathrm{C}\right)$

From the figure it is possible to see that cutting No. 1 is sintered to the state of ceramics, but its firing products have many small and large cracks. The water absorption of the samples varies from $13.0 \%$ for a temperature of $950{ }^{\circ} \mathrm{C}$ to $12.5 \%$ for a temperature of $1100{ }^{\circ} \mathrm{C}$. The products of cutting firing No. 1 are subject to swelling at a firing temperature of $1100{ }^{\circ} \mathrm{C}$ (Fig. 10), which is explained by the presence of carbonates, iron oxide, montmorillonite-contained clay and organic matter.

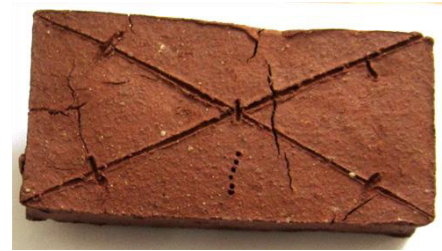

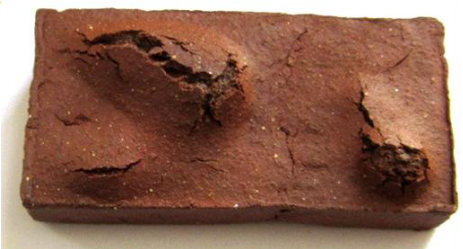

$b$

Fig. 10. Products of firing cutting No. 1 at a temperature of $1100^{\circ} \mathrm{C}: a$ - front side; $b$-reverse side 
Cutting No. 2 forms something like "heat", which collapses even with slight compression by hand. After firing, the samples increase in volume and it is impossible to determine water absorption on them.

Such results are quite consistent with the data on the chemical and mineral composition of cutting. So, cutting No. 1 consists mainly of a clay substance of a polymineral composition containing montmorillonite. By the number of ductility, this cutting is located on the border with medium plastic clays, has high linear air shrinkage and sintering with the formation of a large number of calcining cracks. Such features are characteristic of montmorillonite clayey rocks. The presence in the cutting No. 1 of hydromica, finely divided calcite $(0.004 \mathrm{~mm})$ and albite explains its ability to sinter, especially at a temperature of $1100{ }^{\circ} \mathrm{C}$, and the presence of kaolinite in it prevents complete combustion. The inability of this cutting to bake to low water absorption without signs of burnout is the result of the presence of a significant amount of carbonates, as well as quartz with sufficiently large grains (according to petrography up to $4 \mathrm{~mm}$ ).

Cutting No. 2, on the contrary, contains a little clay substance and is a sand-aleuropelite material consisting of calcium and magnesium carbonates, quartz, and feldspar. It is natural that this material contains a very large number of coarse-grained inclusions (45.3\%), it is located at the border with non-plastic materials by the number of ductility and is not able to form a consolidated ceramic material.

Based on the chemical and mineral composition of the cutting and their properties, it can be concluded that none of them in their pure form can be used as raw materials for the production of wall ceramics. Cutting No. 1 can be considered as a substitute for clay raw materials in mass warehouses, and cutting No. 2 as additive-opacifier to plastic clays with good binding ability or, possibly, as fining additive to red sintered clay.

\section{Conclusions}

1. The chemical-mineral composition and radiological properties of the cutting are established, ecotoxic evaluation of the cutting is carried out, their ceramic-technological characteristics are investigated. It is found that both radioactive cutting are class 1 materials, which allows their use without restrictions in the construction and production of building materials. Both cuttings are characterized by a maximum (close to $100 \%$ ) level of toxicity, which indicates their negative impact on the environment. In terms of chemical and mineral composition, both cuttings are aluminosilicate materials with a high content of iron oxide and calcium. The clay substance of the cutting is polymineral and is represented by kaolinite, montmorillonite and hydromica. It is established that one of the cuttings is close in composition to clayey rocks, the second cutting is a psammite-aleuropelite material with a high content of calcium and magnesium carbonates, quartz and feldspar and a low clay content.

2. According to the results of studying the ceramic-technological properties of cuttings (plasticity number, content of coarse-grained inclusions, particle size distribution, sintering), none of them in their pure form can be used as raw materials for the production of wall ceramics. At the same time, cutting can be considered as a substitute for clay raw materials and as opacifier for plastic clays with the function of fining additives.

\section{References}

[1] Kurhanskyi, V. M., Tishaiev, I. V. (2006). Do pytannia zabrudnennia otochuiuchoho seredovyshcha v protsesi burinnia naftovykh ta hazovykh sverdlovyn. Visnyk KNU imeni Tarasa Shevchenka. Heolohiia, 38-39, 7-9.

[2] Mishunina, A. S. (2015). Metody utilizacii burovykh otkhodov. TPU. Sekciia 2. Burenie neftianykh i gazovykh skvazhin, $125-128$.

[3] Timofeev, E. A., Kuramshina, N. G. (2016). Utilizaciia neftesoderzhaschikh otkhodov i primenenie ikh v stroitelnoi otriasli. Molodoi uchenii, 30, 139-142.

[4] Gaidai, M. F., Vaisman, Ia. I., Glushankova, I. S., Semeinykh, N. S. (2016). Ispolzovanie otkhodov ugledobychi pri proizvodstve stroitelnoi keramiki po ekologicheski bezopasnoi, resursosberegaiuschei tekhnologii. Vestnik MGSU, 3, 93-110.

[5] Dubineckii, V. V. (2015). Burovoi shlam kak istochnik syria dlia proizvodstva stroitelnoi keramiki plasticheskogo formovaniia. Inzhenernii vestnik Dona, 4. Available at: ivdon.ru/ru/magazine/archive/n4y2015/3456

[6] Mymrin, V. A., Alekseev, K. P., Zelinskaya, E. V., Tolmacheva, N. A., Catai, R. E. (2014). Industrial sewage slurry utilization for red ceramics production. Construction and Building Materials, 66, 368-374. doi: http://doi.org/10.1016/j.conbuildmat. 2014.05.036 
[7] Pérez-Villarejo, L., Martínez-Martínez, S., Carrasco-Hurtado, B., Eliche-Quesada, D., Ureña-Nieto, C., Sánchez-Soto, P. J. (2015). Valorization and inertization of galvanic sludge waste in clay bricks. Applied Clay Science, 105-106, 89-99. doi: http:// doi.org/10.1016/j.clay.2014.12.022

[8] Subbota, I. S., Spasonova, L. M., Bulka, T. I., Tokova, M. I. (2019). Zastosuvannia zoloshlakovykh vidkhodiv dlia vyrobnytstva budivelnoi keramiky. Promyslove budivnytstvo ta inzhenerni sporudy, 1, 45-48.

[9] Pronin, S. V. (2009). Problemy utilizacii promyshlennykh otkhodov. Zolnye otkhody. Mashinostroenie i bezopasnost zhiznedeiatelnosti, 6, 37-39.

[10] Khlopytskyi, O. O. (2014). State, problems and prospects of ash-slag waste recycling of Ukrainian thermal power stations. ScienceRise, 4 (2 (4)), 23-28. Doi: http://journals.uran.ua/sciencerise/article/view/28511

[11] Chen, Y., Zhang, Y., Chen, T., Zhao, Y., Bao, S. (2011). Preparation of eco-friendly construction bricks from hematite tailings. Construction and Building Materials, 25 (4), 2107-2111. doi: http://doi.org/10.1016/j.conbuildmat.2010.11.025

[12] Yang, C., Cui, C., Qin, J., Cui, X. (2014). Characteristics of the fired bricks with low-silicon iron tailings. Construction and Building Materials, 70, 36-42. doi: http://doi.org/10.1016/j.conbuildmat.2014.07.075

[13] Zhang, L. (2013). Production of bricks from waste materials - A review. Construction and Building Materials, 47, $643-655$. doi: http://doi.org/10.1016/j.conbuildmat.2013.05.043

[14] Algin, H. M., Turgut, P. (2008). Cotton and limestone powder wastes as brick material. Construction and Building Materials, 22 (6), 1074-1080. doi: http://doi.org/10.1016/j.conbuildmat.2007.03.006

[15] Muñoz, P., Morales, M. P., Mendívil, M. A., Juárez, M. C., Muñoz, L. (2014). Using of waste pomace from winery industry to improve thermal insulation of fired clay bricks. Eco-friendly way of building construction. Construction and Building Materials, 71, 181-187. doi: http://doi.org/10.1016/j.conbuildmat.2014.08.027

[16] Dubineckii, V. V., Gureva, V. A., Vdovin, K. M. (2015). Burovoi shlam v kachestve dobavki v keramicheskii kirpich. Molodoi uchenii, 11 (91), 137-139.

[17] Rakhmatullin, D. V. (2011). Razrabotka kompleksnogo metoda utilizacii burovykh shlamov. Ufa, 146.

[18] DSTU B V.2.7-60-97 Syrovyna hlynysta dlia vyrobnytstva keramichnykh budivelnykh materialiv. Klasyfikatsiia (1997). Available at: http://online.budstandart.com/ua/catalog/doc-page.html?id_doc $=4180$

[19] Andrianov, N. T., Beliakov, A. V. et. al.; Guzman, I. Ia. (Ed.) (2005). Praktikum po tekhnologii keramiki. Moscow: OOO RIF «Stroimaterialy», 195.

[20] DSTU ISO 11269-1:2004. Yakist gruntu. Vyznachennia dii zabrudnykiv na floru gruntu. Chastyna 1: Metod vyznachennia inhibitornoi dii na rist koreniv (2004). Vved. 30.04.2004.

[21] Valerko, R. A. (2013). Osoblyvosti biotestuvannia antropohenno zabrudnenykh gruntiv z metoiu yikh ekotoksychnoi otsinky. Visnyk KhNAU, 2, 262-266.

[22] Metodicheskie rekomendacii «Pochva. Ochistka naselennykh mest. Bytovye i promyshlennye otkhody. Sanitarnaia okhrana pochvy. Obosnovanie klassa opasnosti otkhodov proizvodstva i potrebleniia po fitotoksichnosti: MR 2.1.7.2297-07 (2007). Moscow. Available at: https://znaytovar.ru/gost/2/MR_217229707_Obosnovanie_klass.html

[23] Gluschenko, I. M., Pinsker, A. E., Polianchikov, O. I., Trikilo, A. I. (158). Osnovy nauchnykh issledovanii. Kyiv: Vischa shkola, 1983.

[24] Horova, A., Kulyna, S. (2008). Otsinka toksychnosti gruntiv Chervonohradskoho hirnychopromyslovoho raionu za dopomohoiu rostovoho testu. Visnyk Lvivskoho universytetu, 48, 189-194.

[25] DSTU B V.2.7-60-97 Syrovyna hlynysta dlia vyrobnytstva keramichnykh budivelnykh materialiv. Klasyfikatsiia (1997). Vved. 01.07.1997. 